\title{
Faktor-faktor yang Terkait dengan Rendahnya Pencapaian Wajib Belajar Pendidikan Dasar 9 Tahun
}

\author{
Nur Berlian VA \\ Peneliti Muda pada Puslitjaknov, Balitbang Kemdiknas
}

\begin{abstract}
Abstrak: Penelitian ini bertujuan untuk: 1) memperoleh informasi tentang daerah-daerah yang paling rendah dalam pencapaian Wajar Dikdas; 2)mengkaji faktor-faktor yang terkait dengan rendahnya pencapaian Wajar Dikdas, dan 3) merumuskan alternatif upaya pemecahan masalah penuntasan Wajar Dikdas. Penelitian menggunakan pendekatan kuantitif terhadap data sekunder dan dipadukan dengan pengumpulan data secara kualitatif melalui pengamatan lapangan di beberapa daerah kasus. Hasil temuan:1) Tingkat pencapaian Wajar Dikdas yang rendah didominasi oleh Kawasan Timur Indonesia (KTI), yaitu dimulai dari tingkat SD/MI, sedangkan di wilayah Kawasan Barat Indonesia (KBI) permasalahannya lebih banyak di tingkat SMP/MTs; 2) faktor-faktor penyebab di setiap daerah cukup bervariasi a.I. faktor 1) kemiskinan penduduk, 2) kesulitan menuju sekolah, 3) kurangnya layanan pendidikan, 4) rendahnya motivasi orangtua dan siswa terhadap pendidikan, 5) kurangnya dukungan pemeritah daerah dan masyarakat terhadap pendidikan, serta 6) faktor sosial budaya; 3) alternatif upaya pemecahan masalah penuntasan Wajar Dikdas perlu didasarkan pada faktor penyebabnya, a.I. perlu penghapusan biaya pendidikan a.I. melalui pola subsidi untuk menghapus/meringankan biaya pendidikan, perlu perluasan program alternatif layanan Dikdas, perlu peningkatan sosialisasi dan penghargaan, perlu pengalokasian anggaran pendidikan dengan memprioritaskan kabupaten yang memiliki kapasitas fiskal yang rendah serta peningkatan partisipasi masyarakat dalam program penuntasan Wajar Dikdas.
\end{abstract}

Kata kunci: wajib belajar dan pendidikan dasar

\begin{abstract}
The objectives of the study were 1) to get information about the areas with the lowest attainment of compulsory basic education ( $C B E$ ) by provinces and districts, 2 ) to identify factors related to the low attainment $\mathrm{CBE}$, and 3 ) to formulate an alternative problem solving efforts in completing CBE. The study based on quantitative approach to secondary data combined with qualitative research data through field observation. The findings of this research are: 1) low attainment of CBE dominated by Eastern Region of Indonesia (KTI), started from primary school level, whereas in the Western Region of Indonesia (KBI) more problems found at the secondary shool level, 2) some factors related to attainment of CBE are proverty, geographic condition, education infrastructure, motivation of parent and student, lack of support from local government and communities to education, and sosio culture of community, 3) problem solution should be based on the factors related to the problem: free basic education, education subsidy for poor people, expanding basic education services, improving socialization about $\mathrm{CBE}$, budget allocation priority for poor districts, and increasing public participation in the completion of CBE program.
\end{abstract}

Key words: compulsory education and basic education

\section{Pendahuluan}

Pendidikan merupakan hak dasar bagi setiap warga negara kesatuan Republik Indonesia, seperti yang diamanatkan oleh Undang-Undang Dasar 1945 dan ditindaklanjuti dalam UU Nomor 20 Tahun 2003 tentang Sistem Pendidikan Nasional yang menetapkan bahwa Pemerintah berkewajiban memenuhi hak setiap warga negara untuk memperoleh pendidikan yang bermutu. Sebagai upaya untuk memenenuhi hak dasar tersebut, pemerintah telah menginstruksikan agar setiap warga dapat menempuh pendidikan serendahrendahnya sampai dengan jenjang pendidikan dasar. Hal ini ditegaskan melalui Instruksi Presiden Nomor 1, Tahun 1994 tentang Penuntasan Wajib Belajar Pendidikan Dasar Sembilan Tahun, dan diharapkan tuntas pada tahun 2004. Namun, karena terjadi krisis ekonomi pada tahun 1997, 
program ini tidak dapat memenuhi target. Oleh karena itu, penuntasan Wajar Dikdas 9 Tahun dijadwal ulang dan ditargetkan tuntas pada akhir tahun 2008. Hal tersebut ditegaskan dalam Inpres Nomor 5, Tahun 2006 tentang Percepatan Penuntasan Wajar Dikdas 9 Tahun dan Pemberantasan Buta Aksara. Indikator yang digunakan untuk ketuntasan Wajar Dikdas 9 tahun adalah APM SD/MI/setara dan APK SMP/MTs/setara secara nasional rata-rata mencapai nilai sekurangkurangnya 95 persen.

Walaupun secara nasional Wajar Dikdas sudah dinyatakan tuntas pada akhir tahun 2008 yang ditunjukkan oleh pencapaian APM SD/MI/ setara dan APK SMP/MTs/setara sudah di atas 95 persen, namun pada tingkat provinsi dan kabupaten/kota masih terjadi kesenjangan antardaerah cukup tinggi. Pada tingkat provinsi, pencapaian APM SD/MI/setara berkisar dari paling rendah 85,74 persen (Papua) s.d. paling tinggi 97,12 persen (DKI Jakarta), dan untuk APK SMP/ MTs/setara berkisar 64,46 persen s.d. 106,85 persen. Sedangkan pada tingkat kabupaten/kota, antara kabupaten dengan kota masih terjadi disparitas cukup tinggi terutama untuk APK SMP/ setara yaitu 80,45 persen (rata-rata APK SMP/ Setara kabupaten) dan 92,57 persen (rata-rata APK SMP/Setara kota), sementara untuk APM SD/ $\mathrm{MI} /$ setara tidak ditemukan perbedaan yang berarti antara kabupaten dan kota $(92,85 \%$ dan $92,57 \%)$.

Beberapa permasalahan yang muncul dan akan dijawab melalui penelitian ini adalah 1) Daerah-daerah mana yang memiliki masalah rendahnya pencapaian Wajar Dikdas 9 Tahun?, 2) Faktor-faktor apa yang mempengaruhi rendahnya pencapaian Wajar Dikdas 9 Tahun?, dan 3) Alternatif upaya apa yang diperlukan untuk meningkatkan pencapaian penuntasan Wajar Dikdas 9 Tahun di daerah yang paling rendah pencapaian Wajar Dikdas?

Penelitian ini bertujuan untuk memperoleh bahan kebijakan tentang langkah-langkah dan strategi untuk memperkecil kesenjangan pencapaian Wajar Dikdas 9 Tahun. Secara operasional tujuan pengkajian ini adalah: 1) memperoleh informasi tentang daerah-daerah yang paling bermasalah dalam penuntasan Wajar Dikdas 9 Tahun, 2) mengkaji faktor-faktor yang diduga mempengaruhi rendahnya pencapaian Wajar Dikdas 9 Tahun di daerah yang paling bermasalah, dan 3) merumuskan alternatif upaya pemecahan masalah penuntasan Wajar Dikdas di daerah paling bermasalah dalam penuntasan Wajar Dikdas 9 Tahun.

\section{Kajian Literatur}

Pemerataan Memperoleh Layanan Pendidikan

Pemerataan memperoleh layanan pendidikan memiliki arti pemberian kesempatan yang sama kepada setiap orang untuk memperoleh pendidikan. Pemerataan kesempatan untuk memperoleh pendidikan memiliki dua aspek, yakni persamaan kesempatan (equality, ) dan keadilan (equity). Persamaan kesempatan untuk memperoleh pendidikan mengkaji apakah akses terhadap pendidikan telah merata, sedangkan keadilan dalam memperoleh pendidikan meninjau apakah kesempatan memperoleh pendidikan telah sama antar-berbagai kelompok. Tinjauan keadilan ini dilakukan dengan perbandingan antar-jender (pria/wanita), lokasi geografis (desa/ kota), dan antara penduduk yang kaya dan miskin (Purwadi dan Siswantari, 2002).

Walter Scada (2004) dalam Mahdiansyah (2006) secara jelas membedakan antara equity dan equality. Lebih jauh dikatakan bahwa equity sebagai hak dan equality sebagai persamaan. Equity sebagai hak dapat diterjemahkan sebagai sesuatu yang harus diterima dalam jumlah yang sama oleh setiap elemen. Kemudian equality dapat diartikan sebagai suatu yang benar atau senyatanya terjadi. Pada prinsipnya yang diharapkan oleh semua lapisan adalah equity, namun yang seringkali terjadi dalam kenyataan adalah inequality. Hal yang hampir sama disampaikan oleh Lorena (2000) bahwa equity adalah memberikan apa yang menjadi hak seseorang dan mengakui perbedaan tanpa diskriminasi. Kemudian equality merujuk pada kemiripan antara dua atau lebih, baik secara kuantitas maupun kualitas.

Menurut Psacharopoulos and Woodhall (1997), equity tidak semata-mata hanya ditujukan pada distribusi atau pembagian (sharing) sumber daya di antara individu atau kelompok, namun juga terkait dengan keadilan (justice). Oleh karena itu, berbagai pertimbangan equity hendaknya didasarkan pada fakta-fakta dan pertimbangan 
normative tentang bagaimana sumber daya didistribusikan kepada masyarakat. Dalam kaitan ini, berbagai pertimbangan akan berbeda yang disebabkan oleh perbedaan pandangan masyarakat mengenai prinsip moral dan philosofi. Bahkan, aspek-aspek faktual tentang analisis equity akan menyertakan berbagai pertimbangan tentang bagaimana suatu kelompok yang memiliki sumber daya akan didistribusikan secara berbeda. Dengan kata lain, analisis tentang bagaimana suatu sumber daya akan didistribusikan tidak dapat berhasil jika populasi pertama kali tidak diklasifikasikan ke dalam kelompok yang saling menguntungkan. Dasar pertimbangan untuk pengelompokkan bisa menurut usia, jenis kelamin, strata sosial, tingkat pendapatan, pekerjaan atau variabel relevan lainnya.

Bukti-bukti untuk beberapa kelompok di negara-negara berkembang memiliki akses terhadap pendidikan yang lebih baik dibanding lainnya, tetapi faktor-faktor yang menentukan akses tersebut bervariasi di antara negaranegara. Sebagai suatu gambaran perbedaan partisipasi pendidikan secara individu dikelompokkan menurut jenis kelamin, social ekonomi, kota, desa, suku bangsa, bahasa, dan agama. Sebagai contoh di Malaysia, disparitas terjadi tidak hanya pada laki-laki dan perempuan, serta wilayah geografi, tetapi juga antara suku bangsa Malay dan Cina. Di Sri Lanka, perbedaan etnik dan agama memiliki peran penting dalam peranan pendidikan. Di Peru, bahasa merupakan faktor penentu. Tingkat pendapatan merupakan faktor yang signifikan di Columbia, Malaysia dan di sejumlah negara angka partisipasi sangat bervariasi antara daerah kota dan desa. Sebagai simpulan tentang distribusi pendidikan tergantung pada bagaimana populasi diklasifikasikan dan juga bagaimana partisipasi pendidikan diukur.

Istilah equity dan equality secara nyata sangat berbeda dari sinonimnya, walaupun kadangkadang suka dipertukarkan, khususnya dalam diskusi tentang distribusi pemerataan memperoleh layanan pendidikan. Konsep equity sering diperdebatkan, biasanya terkait dengan isu philosofi dibanding pertimbangan ekonomi (Psacharopoulos and Woodhall, 1997).

Perbedaan lain yang perlu diperjelas adalah akses terhadap pendidikan dan partisipasi, karena distribusi enrollment mungkin terkait dengan sejumlah faktor yang mempengaruhi permintaan pribadi, begitu pun dengan akses terhadap pendidikan di daerah yang berbeda atau area geografi. Misalnya kebijakan pemerintah di beberapa negara mungkin lebih memperhatikan pada penurunan ketidakmerataan akses, alternatifnya adalah dengan membangun sekolah di sejumlah area atau menurunkan biaya untuk mengurangi beban bagi masyarakat yang tidak mampu menyekolahkan anak. Di negara lainnya perhatian terhadap penurunan ketidakmerataan dalam partisipasi pendidikan adalah dengan menyediakan insentif bagi masyarakat yang tidak menyekolahkan anaknya.

Naskah kebijakan sektor pendidikan tahun 1980 menyarankan bahwa perhatian terhadap akses, equity, dan efisiensi secara relatif merupakan fungsi dari tingkat perkembangan pendidikan di suatu negara. Jika angka partisipasi rendah (kurang dari 30\%), pemerintah terutama akan memberi perhatian pada peningkatan akses dengan memperbanyak sekolah untuk memperbanyak murid. Saat angka partisipasi meningkat menjadi $70-80 \%$, perhatian utama menjadi memaksimalkan efisiensi internal dan meyakinkan distribusi pemerataan sumber daya. Kebanyakan analisis distribusi pendidikan di negara-negara berkembang lebih memberi perhatian pada indikator kuantitatif.

Untuk menunjukkan tingkat pemerataan pendidikan digunakan indikator pemerataan. Indikator adalah angka menunjukkan tingkat pemerataan. Indikator yang sering dipakai untuk menganalisis pemerataan memperoleh layanan pendidikan adalah angka partisipasi.

Angka partisipasi adalah perbandingan antara jumlah murid dan jumlah penduduk usia belajar. Penduduk usia Wajar Dikdas 9 Tahun adalah anak umur 7 s.d. 15 tahun. Terdapat dua macam angka partisipasi, yaitu: angka partisipasi kasar (APK) dan angka partisipasi murni (APM).

Angka partisipasi kasar adalah perbandingan antara jumlah siswa (tanpa mempedulikan umurnya) dengan jumlah penduduk usia sekolah jenjang tertentu. Jadi, APK SMP/MTs/setara adalah perbandingan antara jumlah semua siswa SMP/MTS/setara dengan jumlah penduduk usia SMP/MTs/Setara (13 s.d. 15 tahun) di suatu 
daerah, sedangkan angka partisipasi murni (APM) adalah perbandingan antara jumlah siswa kelompok umur yang relevan dengan jumlah penduduk usia sekolah jenjang tertentu. Dengan demikian, APM SMP/MTs/setara adalah perbandingan antara jumlah siswa umur 13 s.d. 15 tahun dengan jumlah penduduk usia 13-15 tahun.

\section{Wajib Belajar}

Ketentuan tentang Wajar Dikdas dituangkan dalam UU Sisdiknas Nomor 20 Tahun 2003 yang antara lain berbunyi sebagai berikut: 1) Pasal 5, ayat 1: Setiap warga negara mempunyai hak yang sama untuk memperoleh pendidikan yang bermutu; 2) Pasal 6, ayat 1: Setiap warga negara yang berusia tujuh sampai dengan lima belas tahun wajib mengikuti pendidikan dasar. Pasal 11, ayat 1: Pemerintah dan Pemerintah Daerah wajib memberikan layanan dan kemudahan serta menjamin terselenggaranya pendidikan bermutu bagi setiap warga Negara tanpa diskriminasi; 3) Pasal 11, ayat 2: Pemerintah dan Pemerintah Daerah wajib menjamin tersedianya dana guna terselenggaranya pendidikan bagi setiap warga negara berusia tujuh sampai dengan lima belas tahun; 4) Pasal 34, ayat 2: Pemerintah dan Pemerintah Daerah menjamin terselenggaranya wajib belajar minimal pada jenjang pendidikan dasar tanpa dipungut biaya, 5) Pasal 34, ayat 3: Wajib belajar merupakan tanggung jawab Negara yang diselenggarakan oleh lembaga pendidikan Pemerintah, Pemerintah Daerah dan masyarakat.

Ketentuan rinci tentang Wajib Belajar selanjutnya diatur dalam Peraturan Pemerintah (PP) No. 47 Tahun 2008. PP tersebut memuat sembilan bab meliputi: ketentuan umum, fungsi dan tujuan, penyelenggaraan, pengelolaan, evaluasi, penjaminan Wajib Belajar, hak dan kewajiban masyarakat, pengawasan, dan ketentuan penutup. Pasal 12 dalam PP tersebut dinyatakan bahwa: 1) Setiap warga negara Indonesia usia wajib belajar wajib mengikuti program wajib belajar; 2) Setiap warga negara Indonesia yang memiliki anak usia wajib belajar bertanggung jawab memberikan pendidikan wajib belajar kepada anaknya; dan 3) Pemerintah kabupaten/kota wajib mengupayakan agar setiap warga negara Indonesia usia wajib belajar mengikuti program wajib belajar.
Dalam rangka penuntasan Wajib Belajar Pendidikan Dasar (Wajar Dikdas) 9 tahun, Pemerintah melalui Instruksi Presiden (Inpres) No 5 tahun 2006 telah menegaskan tentang Gerakan Nasional Percepatan Penuntasan Wajar Dikdas 9 Tahun dan Pemberantasan Buta Aksara. Inpres tersebut merupakan kelanjutan dari Inpres No. 1 Tahun 1994 tentang Penuntasan Wajar Dikdas 9 Tahun yang diharapkan tuntas pada tahun 2004. Namun karena terjadi krisis ekonomi pada tahun 1997, program ini tidak dapat berjalan sebagaimana yang diharapkan, dan akhirnya target tidak tercapai. Oleh karena itu, penuntasan Wajar Dikdas 9 Tahun dijadwal ulang dan ditargetkan tuntas pada akhir tahun 2008. Indikator dan target yang digunakan dalam penuntasan Wajar Dikdas adalah Angka Partisipasi Murni (APM) SD/ MI/setara dan Angka Partisipasi Kasar (APK) SMP/ MTs/sederajat secara nasional mencapai sekurang-kurangnya 95 persen.

\section{Metodologi}

Penelitian dilakukan dengan pendekatan kuantitatif melalui analisis data sekunder terhadap data yang terkait dengan tingkat pencapaian Wajar Dikdas (APM SD/MI/setara, APK SMP/MTs/ setara, jumlah dan persentase anak usia Wajar Dikdas yang tidak sekolah, serta angka melanjutkan lulusan SD/setara ke SMP/setara) dan faktorfaktor yang diduga mempengaruhinya (kemiskinan, kemampuan fiskal Pemda, motivasi orangtua terhadap pendidikan, dan pelayanan Dikdas). Data tersebut bersumber dari Pusat Statistik Pendidikan Balitbang Depdiknas, Ditjen Pendidikan Agama Islam Depag, dan Badan Pusat Statistik. Untuk mendukung analisis data sekunder, dilakukan pengumpulan data kualitatif melalui pengamatan lapangan di daerah-daerah yang memiliki masalah penuntasan Wajar Dikdas.

Analisis data sekunder dilakukan dengan diagram scatter plot yang menunjukkan posisi provinsi atau kabupaten/kota menurut jumlah absolut dan persentase anak tidak sekolah (usia 7-12 tahun untuk SD/setara atau usia 13-15 tahun untuk SMP/setara). Posisi tersebut kemudian dikelompokkan ke dalam empat kuadran dengan cutting point angka rerata nasional tingkat provinsi (untuk analisis antar-provinsi) dan angka rerata nasional tingkat kabupaten/kota (untuk analisis 
tingkat kabupaten/kota). Dengan demikian diperoleh empat posisi kuadran, yaitu: kuadran 1 , untuk daerah yang memiliki jumlah anak tidak sekolah tinggi namun memiliki persentase jumlah anak tidak sekolah yang rendah; kuadran 2, untuk daerah yang memiliki jumlah dan persentase anak tidak sekolah yang tinggi; kuadran 3 , untuk daerah yang memiliki jumlah anak tidak sekolah yang rendah namun memiliki persentase anak tidak sekolah yang tinggi; dan kuadran 4, untuk daerah yang memiliki jumlah dan persentase anak tidak sekolah yang rendah. Daerah yang bermasalah adalah daerah yang berada di posisi kuadran 1, 2, dan 3. Analisis lebih lanjut kemudian dilakukan untuk menemukan faktor-faktor yang diduga mempengaruhi rendahnya pencapaian Wajar Dikdas.

\section{Hasil Penelitian dan Pembahasan}

Dalam kajian ini layanan Dikdas tingkat SD/setara didekati dari jumlah dan persentase anak usia 712 tahun yang tidak sekolah. Semakin tinggi nilainya berarti layanan SD/setara di daerah tertentu semakin rendah, dan demikian sebaliknya.

Berdasarkan diagram scatter plot yang menggambarkan posisi provinsi dan kabupaten/ kota menurut persentase dan jumlah anak usia 7-12 tahun yang tidak sekolah, ditemukan 3 provinsi yang masuk dalam kuadran II atau memiliki persentase dan jumlah anak 7-12 tahun tidak sekolah balina tinaai. vaitu Pabua. NTT. dan
Sulsel, sedangkan untuk tingkat kabupaten/kota ditemukan 60 kabupaten. Dari 60 kabupaten tersebut terdapat 8 kabupaten yang paling bermasalah, yaitu kabupaten yang masuk dalam kuadran II setelah dilakukan dua kali "pengkuadranan". Ke delapan kabupaten yang paling bermasalah tersebut adalah Sumba Barat, Jeneponto, Biak Numfor, Jayapura, Mappi, Merauke, Puncak Jaya, dan Sarmi. Untuk lebih jelasnya, lihat Gambar 1 dan 2.

Kondisi data tersebut menggambarkan bahwa sekalipun Wajar Dikdas pada tingkat SD/ $\mathrm{MI}$ setara secara nasional sudah hampir tuntas (tersisa 0,27\% APM SD/MI/setara untuk mencapai target $95 \%$ ), namun bila ditinjau berdasarkan pencapaian pada tingkat provinsi dan kabupaten/ kota, ditemukan banyak daerah yang masih bermasalah terutama di Kawasan Timur Indonesia khususnya Papua. Dari daerah yang mengalami permasalahan Wajar Dikdas pada tingkat SD/MI/ setara, tidak satupun berasal dari wilayah Indonesia bagian Barat. Dengan demikian dalam hal penuntasan Wajar Dikdas, khususnya pada tingat SD/MI/setara, pemerintah perlu memberi perhatian yang lebih besar terhadap daerahdaerah di wilayah Indonesia Timur.

Dalam kajian ini layanan Dikdas tingkat SMP/ MTs/setara didekati dari jumlah dan persentase anak usia 13-15 tahun yang tidak sekolah. Seperti halnya pada tingkat SD/MI/setara, maka semakin tinggi nilainya berarti layanan SMP/MTs/ Setara di daerah tertentu semakin rendah, dan

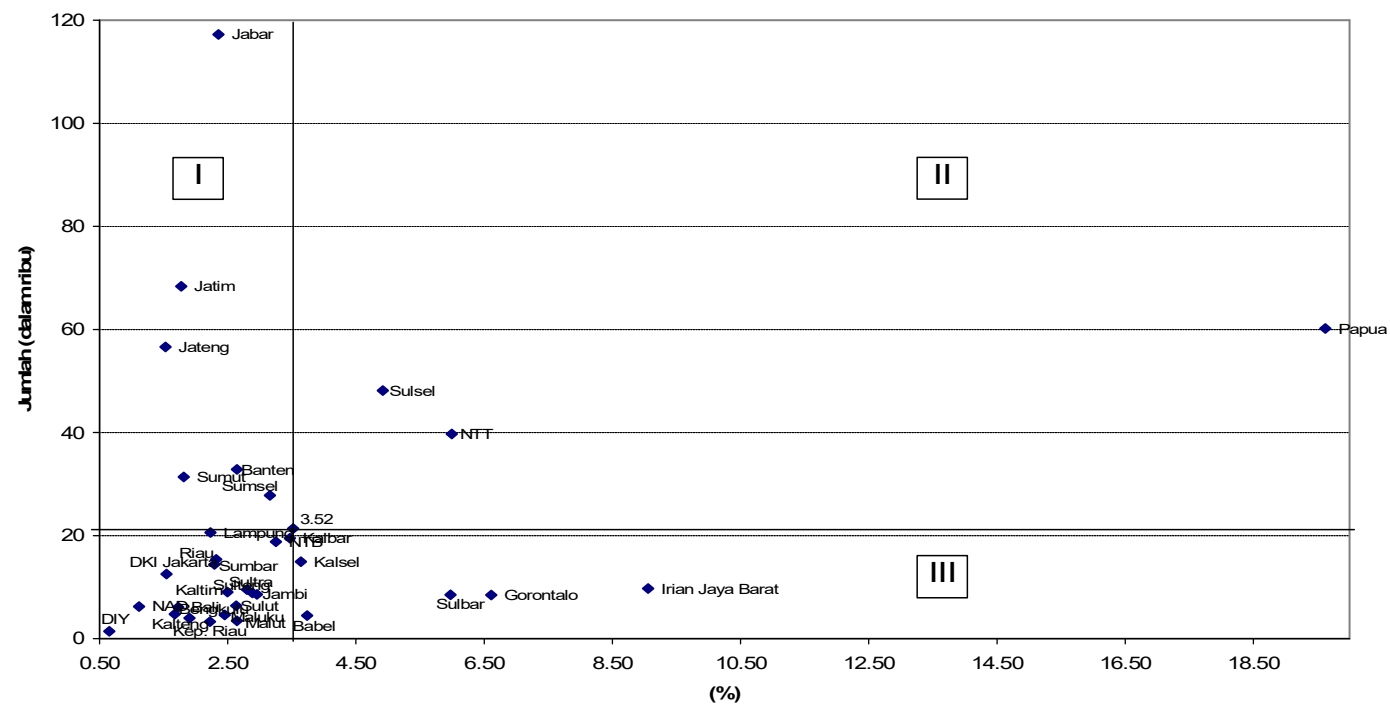

Gambar 1. Penduduk 7-12 tahun yang belum terlayani di SD/MI (angka absolut dan \%) 


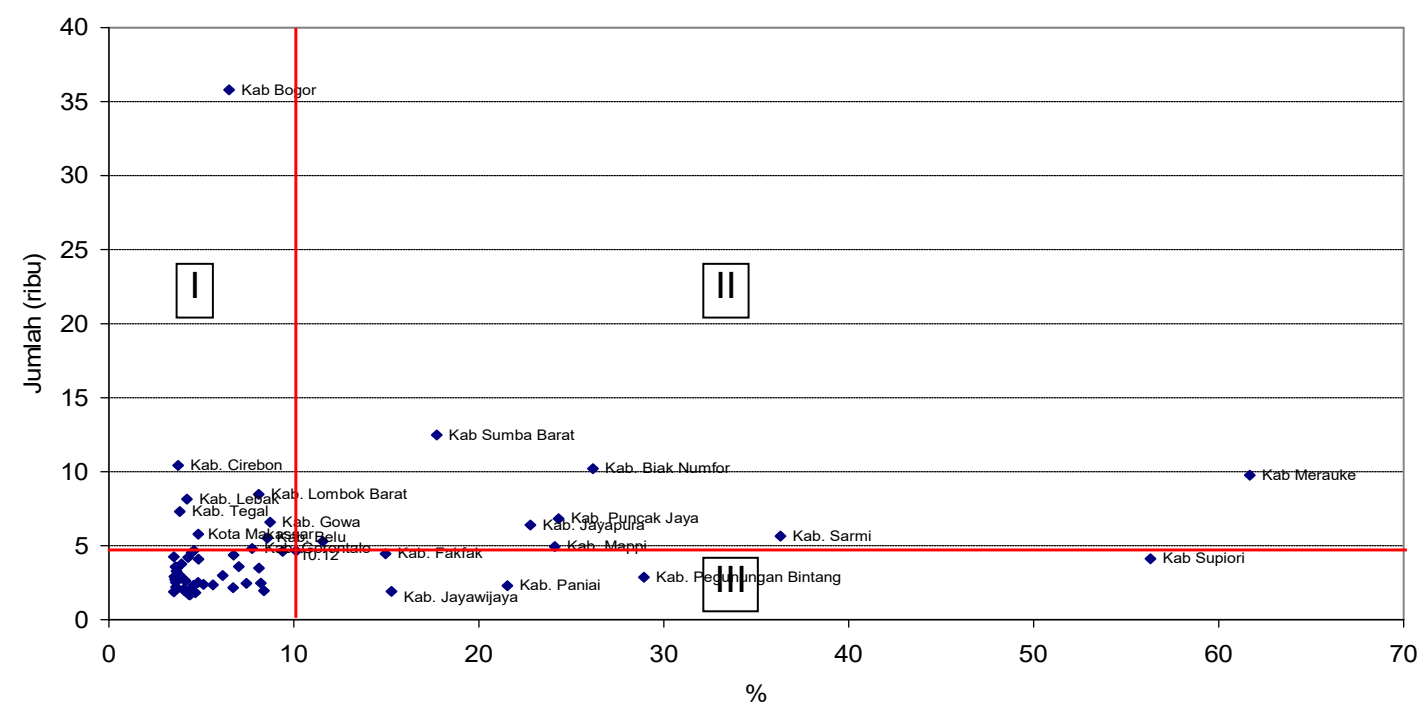

Gambar 2. Posisi Kab/Kota dalam kuadran II tahap I Menurut Jumlah dan Persentase Penduduk 7-12 tahun Tidak Sekolah

demikian sebaliknya. Selain itu, karena untuk masuk SMP/MTs/Setara ada persyaratan harus lulus SD/MI/Setara maka tingkat partisipasi pendidikan pada tingkat SMP/MTs/Setara dikaji juga dari angka melanjutkan lulusan SD/MI/Setara ke SMP/MTs/Setara.

Daerah paling bermasalah dalam jumlah dan persentase anak usia 13-15 tahun tidak sekolah. Ditemukan 6 provinsi yang memiliki persentase dan jumlah anak 13-15 tahun tidak sekolah paling tinggi, yaitu Jabar, Jateng, Banten, Sulsel, Lampung, dan Sumsel. Pada tingkat kabupaten/ kota ditemukan 50 kabupaten/kota yang memiliki persentase dan jumlah anak 13-15 tahun tidak sekolah paling tinggi. Setelah dilakukan dua kali "pengkuadranan", dari ke 50 kabupaten/kota tersebut ditemukan 16 kabupaten yang paling bermasalah karena memiliki jumlah dan persentase anak 13-15 tahun tidak sekolah paling tinggi, yaitu Kabupaten Bogor, Sukabumi, Cianjur, Garut, Cirebon, Karawang, Banjarnegara, Pekalongan, Pemalang, Tegal, Brebes, Probolinggo, Bangkalan, Sampang, Lebak, dan Serang.

Data tersebut menggambarkan bahwa permasalahan Wajar Dikdas pada tingkat SMP/ MTs/setara masih banyak dialami oleh daerahdaerah berpenduduk besar terutama daerah di pulau Jawa. Kondisi ini berbeda dengan permasalahan pada tingkat SD/MI/setara yang didominasi oleh daerah-daerah yang berpenduduk sedikit di
Indonesia Timur. Tidak tampaknya daerah-daerah di Indonesia Timur yang masuk sebagai daerah yang bermasalah dalam permasalahan Wajar Dikdas pada tingkat SMP/MTs/setara disebabkan oleh jumlahnya yang tidak terlalu banyak dibandingkan dengan jumlah anak 13-15 tahun tidak sekolah yang berada di daerah berpenduduk besar, sehingga ketika dilakukan perbandingan antar-daerah terutama dalam hal jumlah anak usia 13-15 tahun yang tidak sekolah maka yang lebih dominan ditemukan adalah daerah-daerah yang berada di pulau Jawa.

Dalam kaitannya dengan penuntasan Wajar Dikdas untuk tingkat SMP/MTs/setara, apabila ke16 kabupaten tersebut lebih diprioritaskan untuk dituntaskan maka yang paling bermasalah adalah karena banyaknya anak usia 13-15 tahun yang tidak sekolah, sehingga hal ini akan memberikan kontribusi yang cukup besar terhadap pencapaian Wajar Dikdas secara nasional. Namun, tidaklah adil apabila daerah-daerah yang memiliki jumlah penduduk sedikit tetapi memiliki persentase anak usia 13-15 tahun yang tidak sekolah cukup tinggi kurang diperhatikan. Terhadap daerah-daerah tersebut, pemerintah juga perlu memberikan perhatian cukup besar.

Daerah paling bermasalah dalam jumlah dan persentase lulusan SD/setara yang tidak melanjutkan ke SMP/setara. Secara nasional terdapat 746.006 orang atau 20,27 persen lulusan SD yang 
tidak melanjutkan ke SMP. Dari jumlah tersebut, Jawa Barat memiliki jumlah lulusan SD yang tidak melanjutkan paling tinggi yaitu 200.576 orang atau 26,89 persen dari nasional. Sedangkan dari persentase ATM, persentase tertinggi ditemukan di Irian Jaya Barat yaitu 35,49 persen, namun dengan jumlah hanya 3.868 orang (Pusat Statistik Pendidikan, 2006).

Provinsi dan kabupaten/kota di wilayah Indonesia Timur yang berpenduduk relatif sedikit, umumnya memiliki masalah Wajar Dikdas dari segi tingginya persentase yang tidak sekolah, sedangkan di Jawa, Sumatera, dan wilayah lain yang berpenduduk besar, umumnya menghadapi masalah dari aspek tingginya jumlah anak yang tidak sekolah.

\section{Faktor-faktor yang terkait dengan rendahnya pencapaian Wajar Dikdas 9 Tahun}

Faktor-faktor yang terkait dengan rendahnya pencapaian Wajar Dikdas dalam pengkajian ini dianalisis dengan menggunakan data sekunder dan hasil pengamatan lapangan. Pengkajian berdasarkan analisis data sekunder sangat tergantung pada ketersediaan data pada tingkat provinsi dan kabupaten, sedangkan kajian berdasarkan pengamatan lapangan lebih bersifat kasus tergantung pada karakteristik daerah yang menjadi objek pengamatan.

Berdasarkan analisis data sekunder, rendahnya pencapaian Wajar Dikdas dapat dikatkan dengan faktor-faktor: (i) kemiskinan penduduk; (ii) kapasitas fiskal Pemda; (iii) faktor geografi (jarak ke sekolah yang jauh); (iv) ketersediaan layanan pendidikan (rasio jumlah anak usia 7-12 tahun per ruang kelas SD/MI atau rasio jumlah anak usia 13-15 tahun per ruang kelas SMP/MTs; dan (iv) tingkat pendidikan penduduk.

Hasil uji korelasi secara nasional terhadap jumlah semua kabupaten/kota dan hanya dengan kabupaten/kota yang memiliki APM lebih rendah ditemukan bahwa faktor tingkat pendidikan penduduk dan kemiskinan memiliki korelasi paling kuat dan signifikan terhadap APM SD/MI. Secara rinci periksa tabel berikut.

Tabel 1. Korelasi antar-variabel yang terkait dengan pencapaian APM SD/MI

\begin{tabular}{|l|l|r|r|}
\hline \multicolumn{1}{|c|}{ Variabel } & \multicolumn{1}{c|}{ Correlation } & APM SD/MI & \multicolumn{1}{c|}{$\begin{array}{c}\text { APM SD/MI di } \\
\text { Kab }\end{array}$} \\
\hline & & $\begin{array}{c}\text { semua } \\
\text { kab/kota }\end{array}$ & $\begin{array}{c}\text { yang < rata2 } \\
\text { nas }\end{array}$ \\
\hline $\begin{array}{l}\text { \%tase penduduk } \\
\text { miskin }\end{array}$ & Pearson Correlation & -0.253 & -0.387 \\
\hline & Sig. (2-tailed) & $0.000^{* *}$ & $0.000^{* *}$ \\
\hline & $\mathrm{N}$ & 439 & 160 \\
\hline \multirow{2}{*}{$\begin{array}{l}\text { Indeks Kapasitas } \\
\text { Fiskal }\end{array}$} & Pearson Correlation & 0.006 & 0.061 \\
\cline { 2 - 4 } & Sig. (2-tailed) & 0.902 & 0.451 \\
\cline { 2 - 4 } & $\mathrm{N}$ & 432 & 154 \\
\hline \multirow{2}{*}{$\begin{array}{l}\text { Kepadatan pddk } \\
\text { (jiwa/km2) }\end{array}$} & Pearson Correlation & 0.010 & 0.112 \\
\cline { 2 - 4 } & Sig. (2-tailed) & 0.828 & 0.157 \\
\cline { 2 - 4 } & $\mathrm{N}$ & 437 & 160 \\
\hline $\begin{array}{l}\text { Rata-rata Lama } \\
\text { Sekolah (thn) }\end{array}$ & Pearson Correlation & 0.324 & 0.526 \\
\cline { 2 - 4 } & Sig. (2-tailed) & $0.000^{* *}$ & $0.000^{* *}$ \\
\cline { 2 - 4 } & $\mathrm{N}$ & 439 & 160 \\
\hline \multirow{2}{*}{$\begin{array}{l}\text { rasio anak 7-12 th } \\
\text { per rg kls SDNS }\end{array}$} & Pearson Correlation & -0.145 & -0.172 \\
\cline { 2 - 4 } & Sig. (2-tailed) & $0.002^{* *}$ & $0.030 * *$ \\
\cline { 2 - 4 } & $\mathrm{N}$ & & 160 \\
\hline
\end{tabular}

Ket : Data diolah dari sumber data BPS (2006), Pusat Statistik Pendidikan (2006), dan Depkeu (2006)

$* *$. Correlation is significant at the 0.01 level (2-tailed).

*. Correlation is significant at the 0.05 level (2-tailed). 
Demikian pula halnya untuk tingkat SMP/MTs, korelasi paling kuat dengan APK ditemukan untuk variabel tingkat pendidikan dan kemiskinan penduduk. Secara rinci periksa Tabel 2 .

Untuk mengetahui lebih jauh kondisi faktorfaktor terkait dengan tingginya jumlah dan persentase anak 7-12 tahun yang tidak sekolah di 3 provinsi dan 8 kabupaten paling bermasalah disajikan pada Tabel 3.
Tabel 3. menunjukkan bahwa terdapat dua variabel yang sangat menentukan tingginya jumlah dan persentase anak 7-12 tahun tidak sekolah yaitu kapasitas fiskal dan tingkat pendidikan yang rendah. Selain itu, tingginya persentase penduduk miskin dan jauhnya jarak ke sekolah juga berpengaruh terhadap angka partisipasi. Tingginya \% penduduk miskin banyak ditemukan di Papua, sedangkan untuk sekolah

Tabel 2. Korelasi antar-variabel yang terkait dengan pencapaian APK SMP/MTs

\begin{tabular}{|c|c|c|c|}
\hline Variabel independen & Correlation & $\begin{array}{l}\text { APK } \\
\text { SMP/MTs } \\
\text { seluruh kab/ } \\
\text { kota }\end{array}$ & $\begin{array}{c}\text { APK SMP/MTs } \\
\text { di kab/kota < } \\
\text { rata2 nas }\end{array}$ \\
\hline \multirow{3}{*}{$\begin{array}{l}\text { Rasio pddk } 13-15 \\
\text { per rg kls smp\&mts }\end{array}$} & Pearson Correlation & -0.456 & -0.355 \\
\hline & Sig. (2-tailed) & $0.000 * *$ & $0.000 * *$ \\
\hline & $\mathrm{N}$ & 429 & 197 \\
\hline \multirow[t]{3}{*}{ Kemiskinan } & Pearson Correlation & -0.251 & -0.430 \\
\hline & Sig. (2-tailed) & $0.000 * *$ & $0.000 * *$ \\
\hline & $\mathrm{N}$ & 439 & 204 \\
\hline \multirow{3}{*}{$\begin{array}{l}\text { Indeks Kapasitas } \\
\text { Fiskal }\end{array}$} & Pearson Correlation & 0.050 & 0.024 \\
\hline & Sig. (2-tailed) & 0.303 & 0.734 \\
\hline & $\mathrm{N}$ & 432 & 204 \\
\hline \multirow{3}{*}{$\begin{array}{l}\text { Kepadatan pddk } \\
\text { (jiwa/km2) }\end{array}$} & Pearson Correlation & 0.200 & 0.112 \\
\hline & Sig. (2-tailed) & $0.000 * *$ & 0.112 \\
\hline & $\mathrm{N}$ & 437 & 204 \\
\hline \multirow{3}{*}{$\begin{array}{l}\text { Rata-rata Lama } \\
\text { Sekolah (thn) }\end{array}$} & Pearson Correlation & 0.634 & 0.566 \\
\hline & Sig. (2-tailed) & $0.000 * *$ & $0.000 * *$ \\
\hline & $\mathrm{N}$ & 439 & 204 \\
\hline
\end{tabular}

Tabel 3. Faktor-faktor yang terkait dengan tingginya jumlah dan persentase anak usia 7-12 tahun yang tidak bersekolah di 3 provinsi APK paling bawah

\begin{tabular}{|c|c|c|c|c|c|}
\hline \multirow[b]{2}{*}{$\begin{array}{c}\text { Prov yg } \\
\text { memiliki jumlah } \\
\& \% \text { anak usia } \\
7-12 \text { thn tidak } \\
\text { sekolah sekolah } \\
\text { tinggi }\end{array}$} & \multicolumn{5}{|c|}{ Faktor-faktor terkait dengan tingginya anak 7-12 thn tidak sekolah } \\
\hline & $\begin{array}{l}\% \text { Penduduk } \\
\text { miskin }\end{array}$ & $\begin{array}{l}\text { Kapasitas } \\
\text { fiskal }\end{array}$ & $\begin{array}{l}\text { Ketersediaan } \\
\text { ruang kls } \\
\text { SD/MI (rasio } \\
\text { jlh anak } 7-12 \\
\text { thn per rg kls } \\
\text { SD/MI) }\end{array}$ & $\begin{array}{l}\text { Jarak ke } \\
\text { sekolah } \\
\text { jauh }\end{array}$ & $\begin{array}{l}\text { Tingkat } \\
\text { pendidikan } \\
\text { penduduk } \\
\text { (rata-rata } \\
\text { lama } \\
\text { sekolah) }\end{array}$ \\
\hline 1. Papua & $\begin{array}{l}\text { Sangat } \\
\text { tinggi }\end{array}$ & Rendah & Sedang & Tinggi & Rendah \\
\hline 2. NTT & $\begin{array}{l}\text { Tinggi } \\
(27,29 \%)\end{array}$ & $\begin{array}{l}\text { Rendah } \\
(0,1332)\end{array}$ & $\begin{array}{l}\text { Tinggi } \\
(383)\end{array}$ & $\begin{array}{l}\text { Rendah } \\
(1,14 \%)\end{array}$ & $\begin{array}{l}\text { Rendah } \\
(6,27)\end{array}$ \\
\hline 3. Sulsel & $\begin{array}{l}\text { Rendah } \\
(14,11 \%)\end{array}$ & $\begin{array}{l}\text { Rendah } \\
(0,2475)\end{array}$ & $\begin{array}{l}\text { Sedang } \\
(497)\end{array}$ & $\begin{array}{l}\text { Tinggi } \\
(13,04 \%)\end{array}$ & $\begin{array}{l}\text { Rendah } \\
(7,17)\end{array}$ \\
\hline Rata2 nasional & $18,74 \%$ & 0,62 & 24,46 & $3,81 \%$ & 7,44 \\
\hline
\end{tabular}

Keterangan: Data diolah dari sumber data BPS (2006), Pusat Statistik Pendidikan (2006), dan Depkeu (2006) 
jauh banyak ditemukan di Papua dan Sulawesi Selatan. Di NTT tidak terlalu tampak jarak ke sekolah yang jauh antara lain disebabkan oleh tipologi daerah yang relatif mengelompok, sehingga jarak ke SD/setara relatif tidak masalah, hal ini didukung pula oleh ketersediaan sarana ruang kelas yang memadai. ketersediaan ruang kelas, jarak ke sekolah yang jauh, dan rendahnya motivasi terhadap pendidikan yang diindikasikan oleh rendahnya tingkat pendidikan penduduk, sedangkan dari faktor kemiskinan tidak tampak keterkaitannya karena persentasenya relatif rendah. Kasus di Kab Sampang agak berbeda, rendahnya pencapaian

Tabel 4. Faktor-faktor yang terkait dengan banyaknya dan tingginya persentase anak usia 7-12 tahun yang tidak bersekolah di 8 kabupaten APK di bawah $80 \%$

\begin{tabular}{|c|c|c|c|c|}
\hline \multirow[b]{2}{*}{$\begin{array}{l}\text { Kabupaten yang } \\
\text { memiliki jumlah \& \% } \\
\text { anak usia } 7-12 \text { thn } \\
\text { tidak sekolah tinggi }\end{array}$} & \multicolumn{4}{|c|}{ Faktor-faktor terkait dengan tingginya anak $7-12$ thn tidak sekolah } \\
\hline & $\begin{array}{l}\% \\
\text { Penduduk } \\
\text { miskin }\end{array}$ & $\begin{array}{l}\text { Kapasitas } \\
\text { fiskal }\end{array}$ & $\begin{array}{l}\text { Ketersediaan } \\
\text { ruang kls SD/MI } \\
\text { (rasio jlh anak } \\
7-12 \text { thn per rg } \\
\text { kls SD/MI) }\end{array}$ & $\begin{array}{l}\text { Tingkat pendidikan } \\
\text { penduduk (rata- } \\
\text { rata lama sekolah) }\end{array}$ \\
\hline 1. Kab Sumba Barat & Tinggi & Rendah & Sangat tinggi & Rendah \\
\hline 2. Kab Jeneponto & Rendah & Rendah & Sangat tinggi & Rendah \\
\hline 3. Kab Biak Numfor & $\begin{array}{r}\text { Sangat } \\
\text { tinggi }\end{array}$ & Rendah & Tinggi & Rendah \\
\hline 4. Kab Jayapura & tinggi & Tinggi & Tinggi & Rendah \\
\hline 5. Kab Mappi & Sedang & Rendah & Sangat tinggi & Rendah \\
\hline 6. Kab Merauke & Sedang & Rendah & Sangat tinggi & Rendah \\
\hline 7. Kab Puncak Jaya & $\begin{array}{l}\text { Sangat } \\
\text { tinggi }\end{array}$ & Tinggi & Sangat rendah & Rendah \\
\hline 8. Kab Sarmi & Sedang & Tinggi & Tinggi & Rendah \\
\hline
\end{tabular}

Ket : Data diolah dari sumber data BPS (2006), Pusat Statistik Pendidikan (2006), dan Depkeu (2006)

Tabel 4. dapat ditafsirkan bahwa rendahnya pencapaian Wajar Dikdas tingkat SD/MI/setara, misalnya untuk kasus di Papua terkait dengan tingginya tingkat kemiskinan, rendahnya kapasitas fiskal Pemda, jauhnya jarak ke sekolah, dan rendahnya motivasi penduduk terhadap pendidikan yang diindikasikan oleh rendahnya tingkat pendidikan penduduk. Begitu pun untuk kasus di Kab Puncak Jaya, rendahnya pencapaian Wajar Dikdas terkait dengan keempat faktor seperti yang dialami oleh provinsi Papua. Dengan penafsiran yang sama seperti di Papua maka dapat ditemukan pula faktor-faktor yang terkait dengan rendahnya pencapaian Wajar Dikdas tingkat SD/MI/setara di provinsi dan kabupaten lainnya yang APK-nya masih rendah.

Sementara itu, untuk tingkat SMP/MTs/setara, faktor-faktor yang dapat dikaitkan dengan rendahnya pencapaian Wajar Dikdas dapat disimak pada Tabel 3 dan Tabel 4. Untuk kasus di provinsi Sulsel, rendahnya pencapaian Wajar Dikdas terkait dengan rendahnya kapasitas fiskal,
Wajar Dikdas lebih terkait dengan tingginya kemiskinan, kapasitas fiskal yang rendah, dan rendahnya motivasi terhadap pendidikan, sedangkan dari faktor ketersedian ruang kelas tidak banyak terkait karena memiliki keadaan sedang.

Selain melakukan analisis data sekunder, identifikasi faktor-faktor yang terkait dengan rendahnya pencapaian Wajar Dikdas juga dilakukan berdasarkan pengamatan lapangan di Kabupaten Lebak, Sumedang, dan Tasikmalaya. Berdasarkan data ini putus sekolah SD hanya ditemukan di Kabupaten Lebak, sedangkan di kabupaten Sumedang dan Tasikmalaya tidak ditemukan. Jika dikaitkan dengan kondisi daerah, Kabupaten Lebak masih relatif banyak daerah yang terpencil bahkan suku terasing (suku Baduy). Faktor-faktor: 1) keadaan geografis, jarak dengan sekolah, 2) tidak adanya akses kendaraan umum ke sekolah, 3) orangtua tidak sanggup membiayai, tingkat pendidikan orangtua, 4) dorongan orangtua, 5) rendahnya motivasi belajar anak, 
Tabel 5. Faktor-faktor yang terkait dengan banyak dan tingginya persentase anak usia 13-15 tahun yang tidak bersekolah di 6 provinsi dengan APK belum tuntas

\begin{tabular}{|c|c|c|c|c|c|}
\hline \multirow[b]{2}{*}{$\begin{array}{l}\text { Provinsi yang } \\
\text { memiliki } \\
\text { jumlah \& \% } \\
\text { anak usia } 13- \\
15 \text { thn tidak } \\
\text { sekolah tinggi }\end{array}$} & \multicolumn{5}{|c|}{ Faktor-faktor terkait dengan rendahnya pencapaian Wajar Dikdas } \\
\hline & $\begin{array}{l}\% \text { Penduduk } \\
\text { miskin (rata2 } \\
\text { nasional = } \\
18,74 \%\end{array}$ & $\begin{array}{l}\text { Kapasitas } \\
\text { fiskal (rata2 } \\
\text { nasional = } \\
0,62 \text { ) }\end{array}$ & $\begin{array}{l}\text { Ketersediaan } \\
\text { ruang kls } \\
\text { SMP/MTs/setara } \\
\text { (rata2 nasional } \\
\text { rasio anak } 13- \\
15 \text { thn per jlh } \\
\text { rg kls } \\
\text { SMP/MTs/setara } \\
=51 \text { ) }\end{array}$ & $\begin{array}{l}\text { Jarak ke } \\
\text { sekolah jauh } \\
\text { (rata2 } \\
\text { nasional = } \\
3,81 \% \text { ) }\end{array}$ & $\begin{array}{l}\text { Tingkat } \\
\text { pendidikan } \\
\text { penduduk } \\
\text { (rata2 } \\
\text { nasional = } \\
7,44 \\
\text { tahun) }\end{array}$ \\
\hline 1. Jabar & $\begin{array}{l}\text { Sangat rendah } \\
(11,62 \%)\end{array}$ & $\begin{array}{l}\text { Sangat rendah } \\
(0,48)\end{array}$ & $\begin{array}{l}\text { Rendah } \\
(58)\end{array}$ & - & $\begin{array}{l}\text { Sedang } \\
(7,55)\end{array}$ \\
\hline 2. Jateng & $\begin{array}{l}\text { Sedang } \\
(20,14 \%)\end{array}$ & $\begin{array}{l}\text { Rendah } \\
(0,33)\end{array}$ & Sedang (50) & Rendah $(4,38)$ & $\begin{array}{l}\text { Rendah } \\
(6,82)\end{array}$ \\
\hline 3. Banten & $\begin{array}{l}\text { Sangat rendah } \\
(8,55 \%)\end{array}$ & $\begin{array}{l}\text { Rendah } \\
(0,79)\end{array}$ & $\begin{array}{l}\text { Rendah } \\
(60)\end{array}$ & \begin{tabular}{|l} 
Rendah \\
$(4,21)$ \\
\end{tabular} & $\begin{array}{l}\text { Sedang } \\
(7,78)\end{array}$ \\
\hline 4. Lampung & $\begin{array}{l}\text { Sedang } \\
(21,48 \%)\end{array}$ & Rendah $(0,45)$ & Sedang (51) & Rendah $(3,8)$ & $\begin{array}{l}\text { Rendah } \\
\text { (7) }\end{array}$ \\
\hline 5. Sumsel & Sedang $(21,17)$ & Rendah $(0,47)$ & Sedang (54) & Rendah $(4,29)$ & $\begin{array}{l}\text { Sedang } \\
(7,55)\end{array}$ \\
\hline 6. Sulsel & $\begin{array}{l}\text { Rendah } \\
(14,11 \%)\end{array}$ & Rendah $(0,58)$ & Rendah (55) & Tinggi $(13,04)$ & $\begin{array}{l}\text { Rendah } \\
(7,17)\end{array}$ \\
\hline
\end{tabular}

Ket : Data diolah dari sumber data BPS (2006), Pusat Statistik Pendidikan (2006), dan Depkeu (2006)

Tabel 6. Faktor-faktor yang terkait dengan banyak dan tingginya persentase anak usia 13-15 tahun yang tidak bersekolah di 16 kabupaten APK rendah

\begin{tabular}{|c|c|c|c|c|}
\hline \multirow[b]{2}{*}{$\begin{array}{ll}\text { Kab yg memiliki tkt } \\
\text { pencapaian } & \text { Wajar } \\
\text { Dikdas } & \\
\text { SD/MI/setara } & \text { yang } \\
\text { rendah } & \end{array}$} & \multicolumn{4}{|c|}{ Faktor-faktor terkait dengan rendahnya pencapaian Wajar Dikdas } \\
\hline & $\begin{array}{l}\% \text { Penduduk } \\
\text { miskin (rata2 } \\
\text { nasional = } \\
18,74 \%\end{array}$ & $\begin{array}{l}\text { Kapasitas fiskal } \\
(\text { rata2 nasional }= \\
0,62)\end{array}$ & $\begin{array}{l}\text { Ketersediaan ruang } \\
\text { kls SMP/MTs/setara } \\
\text { (rata2 nasional } \\
\text { rasio anak } 13-15 \\
\text { thn per jlh rg kls } \\
\text { SMP/MTs/setara = } \\
51 \text { ) }\end{array}$ & $\begin{array}{l}\text { Tingkat } \\
\text { pendidikan } \\
\text { penduduk } \\
\text { (rata2 } \\
\text { nasional = } \\
7,44 \text { tahun) }\end{array}$ \\
\hline 1. Kab Bogor & $\begin{array}{ll}\text { Sangat } & \text { rendah } \\
(11,94) & \\
\end{array}$ & Rendah $(0,2393)$ & Sedang (74) & Sedang $(7,16)$ \\
\hline 2. Kab Sukabumi & Rendah $(14,70)$ & Rendah $(0,1659)$ & Sedang (77) & Sedang $(6,27)$ \\
\hline 3. Kab Cianjur & Rendah $(17,36)$ & Rendah $(0,1337)$ & Sedang (74) & Sedang $(6,35)$ \\
\hline 4. Kab Garut & Rendah $(15,37)$ & Rendah $(0,1638)$ & Sedang (80) & Sedang $(7,14)$ \\
\hline 5. Kab Karawang & Rendah $(13,28)$ & Rendah $(0,2756)$ & Tinggi $(60)$ & Sedang $(6,17)$ \\
\hline 6. Kab Cirebon & Rendah $(16,59)$ & Rendah $(0,1621)$ & Tinggi (66) & Sedang $(6,13)$ \\
\hline 7. Kab Serang & $\begin{array}{l}\text { Sangat rendah } \\
(9,11)\end{array}$ & Rendah $(0,3114)$ & Tinggi (72) & Sedang $(6,99)$ \\
\hline 8. Kab Lebak & Rendah $(12,09)$ & Rendah $(0,2388)$ & Sedang (76) & Sedang $(6,03)$ \\
\hline 9. Kab Tegal & Rendah $(20,53)$ & Rendah $(0,1475)$ & Tinggi (66) & Sedang $(5,70)$ \\
\hline 10. Kab Brebes & Sedang $(29,10)$ & Rendah $(0,846)$ & Sedang (77) & Sedang $(5,51)$ \\
\hline 11. Kab Pemalang & Rendah $(22,31)$ & Rendah $(0,1471)$ & Sedang (74) & Sedang $(6,13)$ \\
\hline 12. Kab Pekalongan & Rendah $(21,50)$ & Rendah $(0,1733)$ & Tinggi (63) & Sedang $(6,50)$ \\
\hline $\begin{array}{l}\text { 13. Kab } \\
\text { Banjarnegara }\end{array}$ & Sedang $(26,91)$ & Rendah $(0,1526)$ & Sedang (76) & Sedang $(5,74)$ \\
\hline 14. Kab Probolinggo & Sedang $(26,17)$ & Rendah $(0,1576)$ & Tinggi (51) & Sedang $(4,98)$ \\
\hline 15. Kab Bangkalan & Sedang $(32,88)$ & Rendah $(0,1297)$ & Sedang (98) & Sedang $(4,94)$ \\
\hline 16. Kab Sampang & Tinggi $(39,75)$ & Rendah $(0,1132)$ & Sedang (95) & Rendah $(3,77)$ \\
\hline
\end{tabular}

Ket: Data diolah dari sumber data BPS (2006), Pusat Statistik Pendidikan (2006), dan Depkeu (2006) 
dan 6) rendahnya kemampuan belajar anak menjadi alasan/penyebab terjadinya putus sekolah.

Lulusan SD yang tidak melanjutkan ke SMP/ setara ditemukan di tiga kabupaten ini. Adapun faktor-faktornya cukup kompleks dan saling berhubungan satu sama lain, antara lain: 1) jarak dari rumah ke SMP/setara sangat jauh (tidak semudah akses ke SD/setara dengan jarak sekitar 3 s.d. $8 \mathrm{~km}$ dengan kondisi jalan terjal dan berbatu); 2) orangtua tidak memiliki cukup biaya untuk menyekolahkan anaknya karena untuk memenuhi kebutuhan sehari-hari saja sangat sulit, biaya yang cukup memberatkan adalah biaya personal yaitu buku, seragam, transpor, dan uang jajan; 3) kemampuan belajar anak yang rendah, didukung oleh rendahnya motivasi orangtua terhadap pendidikan (karena terkait juga dengan faktor ekonomi), dan pengaruh temannya yang juga tidak sekolah; 4) pandangan orangtua bahwa pendidikan bukan merupakan kebutuhan pokok, tamat SD saja sudah cukup karena banyak juga lulusan pendidikan tinggi yang menganggur.

Hasil pengumpulan data kualitatif di beberapa lokasi kecamatan yang memiliki pencapaian Wajar Dikdas yang masih rendah menunjukan bahwa putus sekolah SMP ditemukan di Kabupaten Lebak dan Sumedang, sedangkan di kabupaten Tasikmalaya tidak ditemukan. Melalui hasil pendalaman kasus di kabupaten Lebak diketahui faktor penyebab terjadinya anak putus sekolah adalah 1) jauhnya jarak sekolah dengan tempat tinggal (sekitar 3 s.d. 8 km) dengan kondisi jalan umumnya terjal dan berbatu, 2) tidak tersedia akses kendaraan umum ke sekolah, 3) orang tua tidak sanggup membiayai, 4) orangtua kurang memahami arti pendidikan karena tingkat pendidikan mereka juga rendah, sehingga dorongan orang tua untuk menyekolahkan anaknya sangat kurang, 5) rendahnya motivasi belajar anak, dan 6) rendahnya kemampuan belajar anak menjadi alasan terjadinya putus sekolah SD. Sedangkan di kabupaten Sumedang, putus sekolah siswa SMP a.l. disebabkan oleh faktor: 1) rendahnya motivasi orang tua untuk menyekolahkan anak ke tingkat SMP, 2) motivasi belajar anak yang rendah, dan 3) kemampuan belajar anaknya yang juga rendah.
Alternatif upaya pemecahan masalah rendahnya pencapaian Wajar Dikdas. Upaya-upaya yang perlu dilakukan dalam mempercepat pencapaian Wajar Dikdas perlu didasarkan pada faktor-faktor yang dihadapi oleh setiap daerah yang bersangkutan. Faktor-faktor tersebut bersifat khas tergantung pada karakteristik dan kasus yang dihadapi oleh setiap daerah yang bersangkutan. Secara rinci alternatif upaya pemecahan yang disarankan disajikan pada bagian rekomendasi kebijakan.

\section{Simpulan dan Saran Simpulan}

Provinsi dan kabupaten/kota di wilayah Indonesia Timur pada umumnya memiliki masalah Wajar Dikdas dari segi tingginya persentase anak usia pendidikan dasar yang tidak sekolah. Sedangkan di wilayah Jawa dan Sumatera atau daerah yang memiliki jumlah penduduk cukup tinggi, umumnya menghadapi masalah karena tingginya jumlah anak yang tidak sekolah (angka absolut). Berdasarkan pertimbangan kedua aspek (persentase dan angka absolut), maka ditemukan 3 provinsi yang memiliki persentase dan jumlah anak 7-12 tahun tidak sekolah paling tinggi, yaitu provinsi Papua, NTT, dan Sulsel. Pada tingkat kabupaten/kota ditemukan 7 kabupaten yang paling bermasalah, yaitu Kabupaten Sumba Barat, Kabupaten Jeneponto, Kabupaten. Biak Numfor, Kabupaten. Jayapura, Kabupaten. Mappi, Kabupaten. Merauke, Kabupaten. Puncak Jaya, dan Kabupaten Sarmi.

Untuk anak usia 13-15 tahun, ditemukan 6 provinsi yang memiliki persentase dan jumlah anak 13-15 tahun tidak sekolah paling tinggi, yaitu Jabar, Jateng, Banten, Sulsel, Lampung, dan Sumsel. Sedangkan pada tingkat kabupaten/kota ditemukan 50 kabupaten/kota yang memiliki persentase dan jumlah anak 13-15 tahun tidak sekolah yang tinggi. Dari ke 50 kabupaten/kota tersebut terdapat 16 kab yang memiliki persentase dan jumlah anak 13-15 tahun tidak sekolah paling tinggi, yaitu Bogor, Sukabumi, Cianjur, Garut, Cirebon, Karawang, Banjarnegara, Pekalongan, Pemalang, Tegal, Brebes, Probolinggo, Bangkalan, Sampang, Lebak, dan Serang.

Faktor-faktor yang terkait dengan rendahnya pencapaian Wajar Dikdas di provinsi dan 
kabupaten yang APK-nya masih rendah adalah 1) kemiskinan penduduk; 2) kesulitan menuju sekolah (faktor geografi yang kurang menguntungkan); 3) kurangnya layanan pendidikan; 4) rendahnya motivasi orangtua \& siswa terhadap pendidikan; 5) kurangnya dukungan pemerintah daerah dan masyarakat terhadap pendidikan; serta 6) faktor sosial budaya yang kurang mendukung terhadap pendidikan.

\section{Saran Kebijakan}

Upaya-upaya yang perlu dilakukan untuk mempercepat pencapaian Wajar Dikdas perlu didasarkan pada faktor-faktor yang dihadapi oleh setiap daerah yang bermasalah. Faktor-faktor tersebut bersifat khas tergantung pada karakteristik dan kasus yang dihadapi oleh setiap daerah yang bersangkutan. Berdasarkan faktorfaktor yang mempengaruhinya, maka rekomendasi kebijakan yang dapat diusulkan adalah sebagai berikut.

Upaya pemecahan masalah tingginya anak usia Wajar Dikdas tidak sekolah karena tingginya tingkat kemiskinan: 1) Pembebasan segala jenis pungutan di sekolah terutama bagi anak dari keluarga miskin; 2) Sebagai konsekuensi dari usulan butir 1), maka pemerintah perlu menyediakan subsidi untuk segala keperluan sekolah terutama bagi sekolah yang siswanya banyak berasal dari keluarga miskin, seperti beasiswa miskin, dan beasiswa untuk SMP Terbuka; 3) Pemberian subsidi ke sekolah selama ini telah ditutupi oleh pemerintah Pusat dalam bentuk BOS, sedangkan untuk membantu meringankan biaya pribadi siswa, terutama bagi siswa miskin, maka perlu adanya upaya-upaya terutama dari pemerintah daerah, dan pihak sekolah melalui kerjasama dengan komite sekolah; 4) Pola subsidi pada butir 1) s.d. 3) lebih banyak ditujukan bagi anak usia Wajar Dikdas yang saat ini sudah bersekolah, sedangkan bagi anak yang tidak/belum bersekolah karena putus sekolah, tidak melanjutkan, atau belum sekolah sama sekali belum tersentuh. Untuk itu perlu diupayakan pola-pola pemberian subsidi bagi anak usia Wajar Dikdas yang belum/tidak bersekolah agar bisa masuk sekolah.

Upaya pemecahan masalah tingginya anak usia Wajar Dikdas tidak sekolah karena sulitnya akses menuju sekolah. Sulitnya akses menuju sekolah terutama lebih banyak terjadi pada tingkat SMP/setara, sedangkan untuk akses menuju SD/setara pada umumnya relatif sudah baik. Untuk itu disarankan agar pemerintah perlu bekerjasama dengan masyarakat setempat berupaya menyediakan layanan pendidikan SMP/ setara yang mudah terjangkau atau dekat dengan pemukiman penduduk, seperti halnya akses menuju SD. Program yang selama ini telah berjalan seperti pembukaan SD-SMP Satu Atap, SMP Terbuka, dan Paket B jumlahnya masih terbatas dan belum menjangkau semua daerah kantong yang memiliki banyak lulusan SD yang tidak melanjutkan. Layanan program ini masih belum meluas sampai ke setiap pemukiman penduduk seperti halnya SD, namun masih terbatas di pusat kecamatan atau desa. Dengan demikian kampung-kampung lain yang memiliki jarak cukup jauh dengan pusat kecamatan atau desa masih perlu memperoleh layanan program ini.

Upaya pemecahan masalah tingginya anak usia Wajar Dikdas tidak sekolah karena rendahnya motivasi orangtua terhadap pendidikan: 1) peningkatan sosialisasi tentang pentingya pendidikan; 2) pemberian penghargaan bagi daerah-daerah yang cukup berhasil dalam menuntaskan program Wajar Dikdas. Selain itu karena rendahnya motivasi juga terkait dengan faktor lain yaitu rendahnya kemampuan ekonomi, maka pemecahan masalah dapat diintegrasikan dengan faktor tersebut.

Upaya pemecahan masalah tingginya anak usia Wajar Dikdas tidak sekolah karena kurangnya perhatian Pemda terhadap pembangunan pendidikan: 1) pengalokasian anggaran pendidikan dari Pusat ke Kabupaten dengan memprioritaskan kabupaten yang memiliki kapasitas fiskal yang rendah, seperti Dana Alokasi Khusus (DAK); 2) peningkatan partisipasi masyarakat dalam program penuntasan Wajar Dikdas. 


\section{Pustaka Acuan}

Instruksi Presiden No. 1 Tahun 1994 tentang Wajib Belajar Pendidikan Dasar 9 Tahun. Jakarta: Sekretariat Negara.

Instruksi Presiden No. 5 Tahun 2006 tentang Gerakan Nasional Percepatan Penuntasan Wajib Belajar Pendidikan Dasar 9 Tahun dan Pemberantasan Buta Aksara. Jakarta: Sekretariat Negara.

Lorena, Aguilar, Lic. 2000. Definitions of Equity and Equality, Pop Planet, Juli 2000.

Mahdiansyah, 2006. Studi Pemerataan Perguruan Tinggi, Fakultas, dan Program Studi Antar-Wilayah Indonesia Sesuai dengan Kebutuhan Masing-Masing. Jakarta: Puslitjaknov, Balitbang Depdiknas.

Peraturan Pemerintah Nomor 47 Tahun 2008 tentang Wajib Belajar. Jakarta: Depdiknas.

Pusat Statistik Pendidikan, 2006. Statistik Persekolahan SD 2005/2006. Jakarta: Pusat Statistik Pendidikan, Balitbang Depdiknas.

, 2006. Statistik Persekolahan SMP 2005/2006. Jakarta: Pusat Statistik Pendidikan, Balitbang Depdiknas.

2006. Indonesia Educational Statistics in Brief 2005/2006. Jakarta: Pusat Statistik Pendidikan, Balitbang Depdiknas.

Psacharopoulos, G. and M. Woodhall. 1997. Education for Development. New York: Oxford University Press for The World Bank.

Purwadi, Agung dan Siswantari. 2002. Analisis Pemerataan Kesempatan Memperoleh Pendidikan. Seri Analisis Kebijakan Pendidikan, Buku 3. Jakarta: Puslitjak, Depdiknas.

Undang-Undang Dasar Republik Indonesia Tahun 1945. Jakarta: DPR RI.

Undang-Undang Nomor 20 Tahun 2003 tentang Sistem Pendidikan Nasional. Jakarta: Depdiknas. 